\title{
Clinical evidence of efficacy of red yeast rice and berberine in a large controlled study versus diet
}

\author{
Bruno Trimarco • Claudio Benvenuti • \\ Francesco Rozza · Claudia Sara Cimmino • \\ Renata Giudice $\cdot$ Salvatore Crispo
}

Received: 25 May 2010/Accepted: 30 November 2010 / Published online: 3 February 2011

(C) The Author(s) 2011. This article is published with open access at Springerlink.com

\begin{abstract}
Efficacy of a new patented proprietary combination of natural nutraceuticals (PN) containing natural hypolipidemic as red yeast, policosanol and berberine was tested in a large study on dyslipidemic patients in clinical practice. A parallel, controlled, randomized, multicenter study was designed. After 2 weeks on a stable dietary regimen, the patients were randomized to PN 1 tablet/day associated with diet $(\mathrm{PN}+\mathrm{D})$ or diet alone (D) for 16 weeks. Entry criteria were: Tot-Chol $>200 \mathrm{mg} / \mathrm{dL}$ or LDL-Chol $>150 \mathrm{mg} / \mathrm{dL}$ without a clear indication for statins, or plasma triglycerides $>150 \mathrm{mg} / \mathrm{dL}$. Lipid pattern and CV parameters were evaluated at baseline and monthly. 1,751 patients were enrolled in 248 Italian units, 933 patients on $\mathrm{PN}+\mathrm{D}$ and 818 on $\mathrm{D}$. The baseline lipid values were: Tot-Chol 255.4 versus $243.1 \mathrm{mg} / \mathrm{dL}$, LDLChol 170.1 versus $162.2 \mathrm{mg} / \mathrm{dL}$, HDL-Chol 50.0 versus $48.8 \mathrm{mg} / \mathrm{dL}$, and TG 190.5 versus $184.4 \mathrm{mg} / \mathrm{dL}$. PN constantly and significantly improved lipid parameters versus D group: at 16 weeks -19.1 versus $-9.4 \%$ for Tot-Chol $(p<0.001),-23.5$ versus $-10.8 \%$ for LDLChol $(p<0.001),+11.6$ versus $+4.0 \%$ for HDL-Chol $(p<0.001),-17.9$ versus $-11.3 \%$ for TG $(p<0.001)$. In conclusions, PN plus diet allows an effective
\end{abstract}

The members of Armoweb Study Group has been given in the Appendix.

B. Trimarco $(\bowtie) \cdot$ F. Rozza · C. S. Cimmino - R. Giudice ·

S. Crispo

Department of Clinical Medicine, Cardiovascular and

Immunological Sciences, Federico II University,

Via Sergio Pansini 5, bld 2, 80131 Naples, Italy

e-mail: trimarco@unina.it

C. Benvenuti

Medical Department, Rottapharm Madaus, Monza, Italy improvement of blood lipids with a significant reduction of global CV risk, suggesting a role for $\mathrm{PN}$ in $\mathrm{CHD}$ prevention.

Keywords Metabolic syndrome - Nutraceuticals · Berberine $\cdot$ Red yeast $\cdot$ Dyslipidemia

\section{Introduction}

Lifestyle and diet changes are very important actions to be taken to improve the cardiovascular risk and should precede any pharmacological intervention on hypercholesterolemia, which is a well-known risk factor for coronary artery, cerebrovascular and peripheral artery diseases [1-3].

Dietary counseling will take advantage from the recommendations to integrate diet with the introduction of a food supplement resulting in an improved compliance with a dietary regimen. Indeed, previous studies suggested that the combination of food supplements with diet leads to an improvement of lipid metabolism control $[4,5]$.

Furthermore, food supplements, reinforcing the subject's motivation to comply with the lifestyle changes, can lead to postpone the prescription of hypo-lipidemic therapy and the resulting risk of adverse reactions, and even to be used as effective treatment in statin intolerant patients [6].

Many nutraceuticals are currently commercially available claiming an anti-dyslipidemic effect. The criteria for a correct selection include the guarantees that good manufacturing practice is as accurate as the one adopted for drug manufacturing, that the quality assurance allows to obtain a finished product with a standardized constant composition, and that clinical studies document the claims supporting the clinical evidence of efficacy and safety. 
A recent opportunity offered by from the pharmaceutical research and development is represented by a patented proprietary combination of chemically well defined natural nutraceuticals (PN) [7]. This combination was designed to cover more $\mathrm{CV}$ risk factors with active principles for the control of plasma cholesterol (red yeast rice extract, policosanol, berberine), of triglycerides (berberine), of homocysteine (folic acid) and containing antioxidants (coenzyme $\mathrm{Q}_{10}$ and asthaxantin) [4, 5, 7, 8].

The major components of PN are red yeast rice extract, which contains monacolins that compete structurally at HMGCoA reductase level with HMGCoA, precursor of mevalonate, thus reducing plasma cholesterol [10, 11], and Berberine, a natural plant extract from Berberis aristata bark, reducing cholesterolemia by increasing LDL-Chol receptor on the liver cell surface, and inhibiting triglycerides biosynthesis via the activation of AMP activated proteokinase [12, 13].

In clinical studies, red yeast rice significantly reduced total and LDL cholesterol [14] and also Berberine improved triglycerides [15].

Clinical activity on Total and LDL cholesterol of PN combined with diet are documented in a controlled clinical study versus Berberine alone in moderate hypercholesterolemia [4].

The purpose of this study was to investigate the clinical effect on lipid profile and safety of PN added to diet and lifestyle management versus diet alone in hyperlipidemic patients in an extended multicenter-randomized study in clinical practice.

\section{Materials and methods}

A parallel, longitudinal, controlled, randomized, within centers, multicenter study was carried out to compare PN added to diet (PN $+\mathrm{D})$ versus the control group receiving diet alone (D) by Italian general practitioners (GPs). Each GP was supposed to enroll 10 dyslipidemic patients (18-80 year) with or without metabolic syndrome, not requiring a drug therapy in accordance with ATPIII guidelines, or who had demonstrated side effects or had contraindications to lipid-lowering drug treatment. Dyslipidemia was defined as total cholesterol levels $>200 \mathrm{mg} / \mathrm{dl}$ and/or LDL cholesterol levels >150 mg/dl and/or triglycerides levels $>150 \mathrm{mg} / \mathrm{dl}$. The principles of Helsinki Declaration were applied, and specifically an informed consent was supplied and the subject's right to withdraw from the study without giving reason was clearly allowed.

Pregnant or breast-feeding women and patients treated with anti-hypertensive and/or lipid lowering drugs were excluded.
The composition of the patented proprietary combination of nutraceuticals investigated is as follows: red yeast rice extract $200 \mathrm{mg}$ (equivalent to $3 \mathrm{mg}$ monacolins), policosanol $10 \mathrm{mg}$, berberine $500 \mathrm{mg}, 0.2 \mathrm{mg}$ folic acid, coenzyme $\mathrm{Q}_{10} 2 \mathrm{mg}$, and asthaxantin $0.5 \mathrm{mg}$ (Armolipid Plus, RottapharmlMadaus).

All the patients were recommended to follow a lowglucose, low-calorie, low-fat dietary regimen in accordance with their clinical conditions, whilst the PN group added one tablet/day of PN. The treatment lasted 16 weeks.

Serum lipid pattern and vital signs were measured at baseline and every 4 weeks. (Tot-Chol, HDL-Chol, LDLChol, TG). Anthropometric and cardiovascular parameters were evaluated at baseline and every 4 weeks. At the end of the study, the patients expressed an overall judgment on the treatment acceptance by the following score: $0=$ null, $1=$ moderate, $2=$ fair, $3=$ good, $4=$ very good. Fasting plasma glucose and lipid levels were measured by standard methods. Waist circumference was measured at each visit at midway between the lowest rib and the iliac crest using an anthropometric tape. Systolic and diastolic BP values were measured with the aid of a standard sphygmomanometer after $5 \mathrm{~min}$ in sitting position, according to the guidelines of the European Society of Hypertension/European Society of Cardiology (VB-Guidelines ESC/ESH 2007). Three BP values were obtained in the sitting position at 2 min intervals. The averages of these measurements were used for the analysis.

Adverse events, intercurrent diseases and compliance were also checked at 4 weeks intervals during the active treatment phase.

\section{Statistical analysis}

Sample potency for comparison between two independent samples was run assuming a similar sample size (N1/ $\mathrm{N} 2=1)$ and a small effect size $(0.20)$ for an $\alpha$-error probability of 0.05 and a potency of 0.90 , requiring a total population sample of 1,052 observations [9]. Data were analyzed using Excel statistical software and expressed as average \pm SEM. The statistical analysis on baseline homogeneity and clinical efficacy was carried out by means of $\chi^{2}$-test and analysis of variance (ANOVA), applied when appropriate on the patients collected from the centers which complied with the controlled design. A comparison between the two arms was done using absolute differences and analyzed by ANOVA test. The null hypothesis was rejected for 2 -tail $\alpha<0.05$.

A computerized internet procedure was used: each center was endowed with individual login and password to allow a protected access to the website http://www.armolipid.net for data input and results analysis. 


\section{Results}

The study was carried out in 248 centers on 1,751 dyslipidemic patients randomized to $\mathrm{PN}+\mathrm{D}$ (933 cases) and D groups (818 cases).

At start no clinically significant differences were present between the two groups concerning age, gender, BMI and waist circumference (Table 1).

The baseline clinical parameters, such as systolic and diastolic blood pressure values, heart rate, Tot-Chol, LDLChol, HDL-Chol, TG, fasting plasma glucose and body weight, were clinically compared between the two study groups (Table 2).

After 4 weeks of treatment, the average reduction of Tot-Chol versus the baseline was $-9.3 \%$ in the PN + D group and $-5.4 \%$ in the D group and gradually reached, respectively, -19.1 and $-9.4 \%$ after 16 weeks, with $p<0.001$ between treatments for all times (Fig. 1).

Likewise, the reduction of LDL-Chol was $-11.9 \%$ in $\mathrm{PN}+\mathrm{D}$ group and $-5.9 \%$ in D group at the 4 th week check and progressively attained correspondingly $-23.5 \%$ in $\mathrm{PN}+\mathrm{D}$ and $-10.8 \%$ in D groups at the 16th week (Fig. 2).

HDL-Chol levels showed a moderate increase from $+5.1 \%$ for $\mathrm{PN}+\mathrm{D}$ and $+1.2 \%$ for $\mathrm{D}$ after 4 weeks of treatment up to $+11.6 \%$ for $\mathrm{PN}+\mathrm{D}$ and $+4.0 \%$ for $\mathrm{D}$ after 16 weeks (Fig. 3).

The reduction of plasma triglycerides was $-12.7 \%$ in $\mathrm{PN}+\mathrm{D}$ group and $-8.1 \%$ in $\mathrm{D}$ at the 4 th week down to $-17.9 \%$ on $\mathrm{PN}+\mathrm{D}$ and $-11.3 \%$ on $\mathrm{D}$ at the 16 th week (Fig. 4).

The difference between treatments was statistically significant at all time points for all the lipid parameters with $p<0.001$.

Body weight decreased similarly in the groups, respectively, for $\mathrm{PN}+\mathrm{D}$ and D groups: -2.0 and $-1.9 \%$ at 4 weeks, -3.3 and $-3.0 \%$ at 8 weeks, -4.5 and $-4.0 \%$ at 12 weeks, -4.8 and $-3.9 \%$ at 16 weeks.

A positive relationship between hypocholesterolemic effect of PN + D and the baseline value of LDL-Cholesterolemia was detected at the 12 th week (Fig. 5).

The normalization rate of total cholesterolemia ( $\leq 190 \mathrm{mg} / \mathrm{dL}$ ) achieved during PN + D was higher than with diet alone and the difference was statistically significant $(p<0.01)$ starting from the 8th week (Fig. 6).
Mainly mild and moderate unwanted events judged by the physician with a probable, possible or certain correlation with the treatment were reported in $27 / 933$ cases $(2.9 \%)$ during PN + D treatment and 4/818 cases $(0.5 \%)$ during $\mathrm{D}$. Treatment withdrawal was reported in 8 cases $(0.86 \%)$ on $\mathrm{PN}+\mathrm{D}$ for the following reasons: asthenia, CPK increase, diarrhea, myalgia, dyspepsia (2), gastralgia (2). All these events, save gastralgia, had previously appeared in the same patients also with statins (Table 3).

The treatment efficacy was assessed by the physician as good + very good in $71.7 \%$ of cases with $\mathrm{PN}+\mathrm{D}$ and in $24.8 \%$ of cases with $\mathrm{D}(p<0.001)$ and was confirmed by the treatment acceptance evaluated by the patient as good + very good in $80.1 \%$ of cases with $\mathrm{PN}+\mathrm{D}$ and in $29.1 \%$ of cases with $\mathrm{D}(p<0.001)$.

\section{Discussion}

The present randomized controlled study provides evidence that the addition to diet and lifestyle changes of a patented combination of natural nutraceuticals (PN), based on red yeast rice extract and berberine, can improve significantly the lipid profile versus diet alone in dyslipidemic subjects in whom a hypolipidemic therapy is not yet indicated or not well tolerated or is contraindicated.

The study produced reliable and robust data, because obtained in a very large representative sample of the general population, according to a correct methodological design, for an adequate duration of treatment, under conditions adherent to the usual daily clinical practice. These considerations and the planned lack of diet standardization allow the outcome of this study to be extrapolated to the general population. Moreover, the results are in agreement with the ones reported in a preliminary controlled doubleblind clinical study versus an active control group in moderate hyperlipidemia [4].

The effect on lipids was independent of the diet as both groups showed a similar and parallel reduction of body weight during treatment, proving that the dietary restrictions were adopted by the whole sample.

Indeed, the opportunity of prescribing active nutraceuticals can favor the compliance with the dietary changes

Table 1 Vital characteristics at study baseline (average \pm SEM)

\begin{tabular}{llllll}
\hline Group & Age (years) & Gender $(\%$ F/M) & BMI $\left(\mathrm{kg} / \mathrm{m}^{2}\right)$ & Weight $(\mathrm{kg})$ & Waist circ. $(\mathrm{cm})$ \\
\hline $\mathrm{D}(n=933)$ & $55.6 \pm 0.4$ & $55.5 / 44.5$ & $28.4 \pm 0.2$ & $78.4 \pm 0.5$ & $99.0 \pm 0.5$ \\
$\mathrm{PN}+\mathrm{D}(n=818)$ & $57.3 \pm 0.4$ & $53.1 / 46.9$ & $27.9 \pm 0.2$ & $77.0 \pm 0.5$ & $98.4 \pm 0.5$ \\
$p$ & $p<0.01$ & NS & $p<0.05$ & $p<0.05$ & NS \\
\hline
\end{tabular}

$p$ statistical significance between groups 
Table 2 Clinical characteristics at study baseline in $\mathrm{D}(n=933)$ and $\mathrm{PN}+\mathrm{D}(n=818)$ groups (average \pm SEM)

\begin{tabular}{lllllllll}
\hline Group & $\begin{array}{l}\text { SBP } \\
(\mathrm{mmHg})\end{array}$ & $\begin{array}{l}\mathrm{DBP} \\
(\mathrm{mmHg})\end{array}$ & $\begin{array}{l}\text { HR } \\
(\mathrm{b} / \mathrm{min})\end{array}$ & $\begin{array}{l}\text { Tot Chol } \\
(\mathrm{mg} / \mathrm{dL})\end{array}$ & $\begin{array}{l}\text { LDL-Chol } \\
(\mathrm{mg} / \mathrm{dL})\end{array}$ & $\begin{array}{l}\text { HDL-Chol } \\
(\mathrm{mg} / \mathrm{dL})\end{array}$ & $\begin{array}{l}\text { TG } \\
(\mathrm{mg} / \mathrm{dL})\end{array}$ & $\begin{array}{l}\text { Glycaemia } \\
(\mathrm{mg} / \mathrm{dL})\end{array}$ \\
\hline $\mathrm{D}$ & $134.3 \pm 0.5$ & $81.3 \pm 0.3$ & $74.4 \pm 0.3$ & $243.1 \pm 1.0$ & $162.2 \pm 1.0$ & $48.8 \pm 0.4$ & $184.4 \pm 1.9$ & $99.2 \pm 20.4$ \\
$\mathrm{PN}+\mathrm{D}$ & $134.3 \pm 0.5$ & $81.5 \pm 0.3$ & $73.6 \pm 0.3$ & $255.4 \pm 1.1$ & $170.1 \pm 1.1$ & $50.0 \pm 0.5$ & $190.5 \pm 2.1$ & $99.6 \pm 20.8$ \\
$p$ & $\mathrm{NS}$ & $\mathrm{NS}$ & $p<0.05$ & $p<0.01$ & $p<0.01$ & $p=0.06$ & $p<0.05$ & $\mathrm{NS}$ \\
\hline
\end{tabular}

$S B P$ systolic blood pressure, $D B P$ diastolic blood pressure, $p$ statistical significance between groups

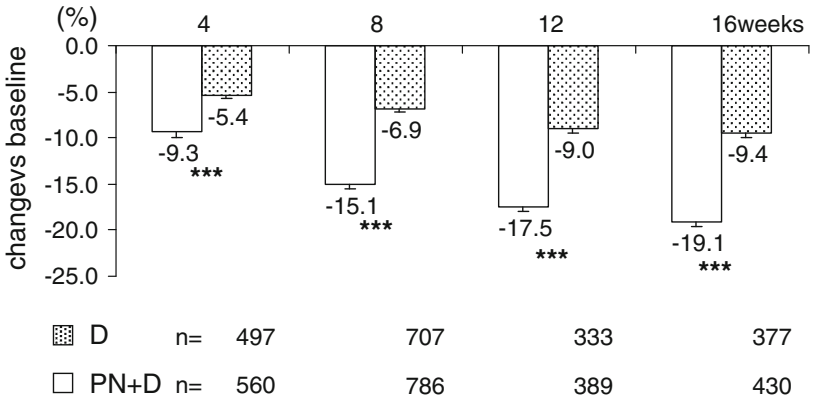

Fig. 1 Total cholesterol reduction (\%) versus baseline during diet alone or plus PN (Average \pm SEM, $* * * p<0.001$ between treatments)

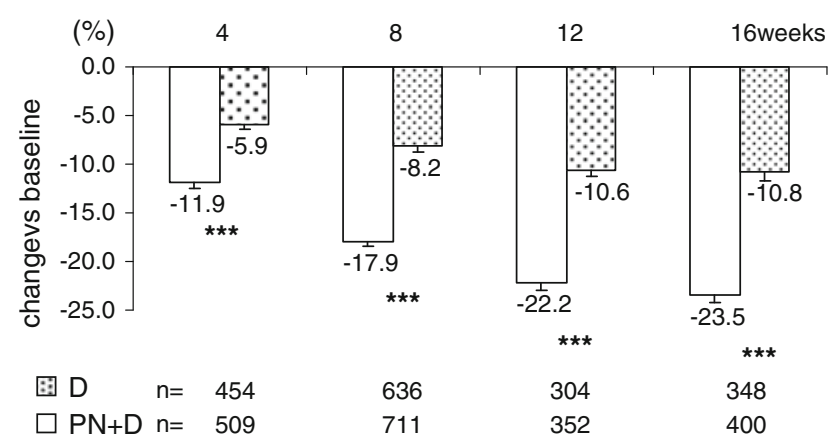

Fig. 2 LDL-Cholesterol reduction (\%) versus baseline during diet alone or plus PN. (Average \pm SEM, $* * * p<0.001$ between treatments)

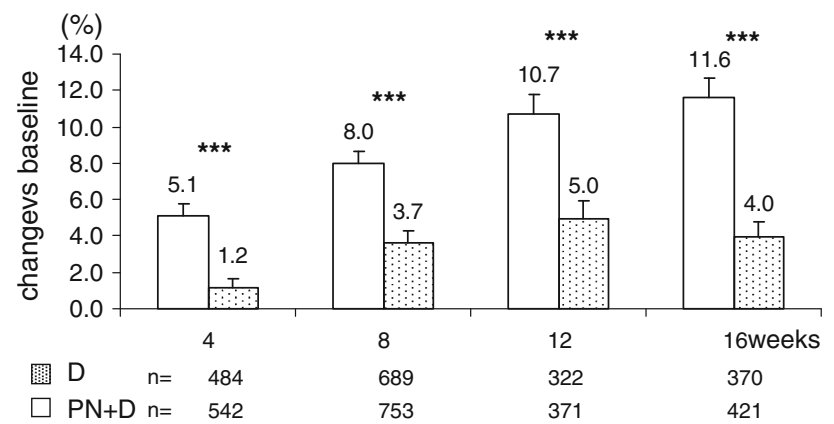

Fig. 3 HDL-Cholesterol reduction (\%) versus baseline during diet alone or plus PN. (Average \pm SEM, $* * * p<0.001$ between treatments)

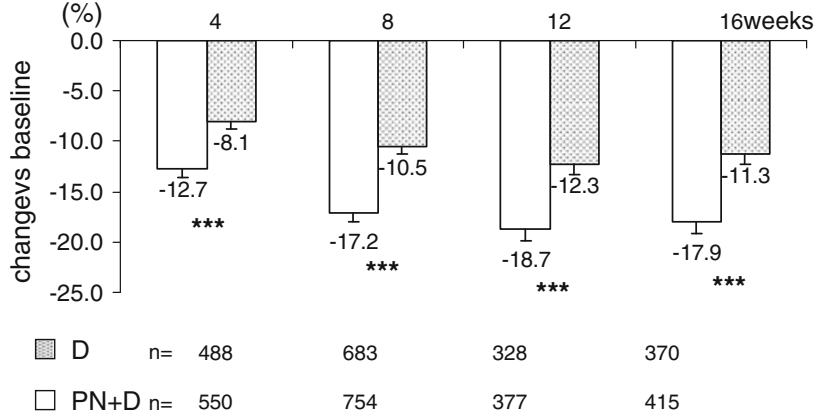

Fig. 4 Triglycerides reduction (\%) versus baseline during diet alone or plus PN. (Average \pm SEM, $* * * p<0.001$ between treatments)

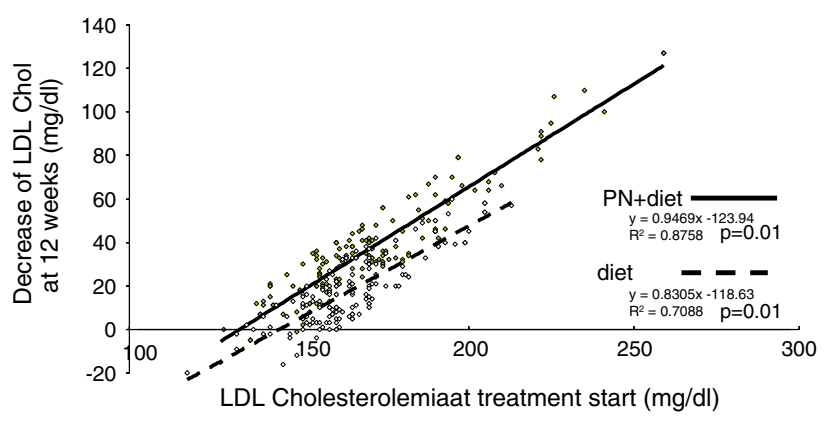

Fig. 5 Relationship between hypocholesterolemic effect of $\mathrm{PN}+$ Diet and the baseline value of total cholesterolemia at the 8th week

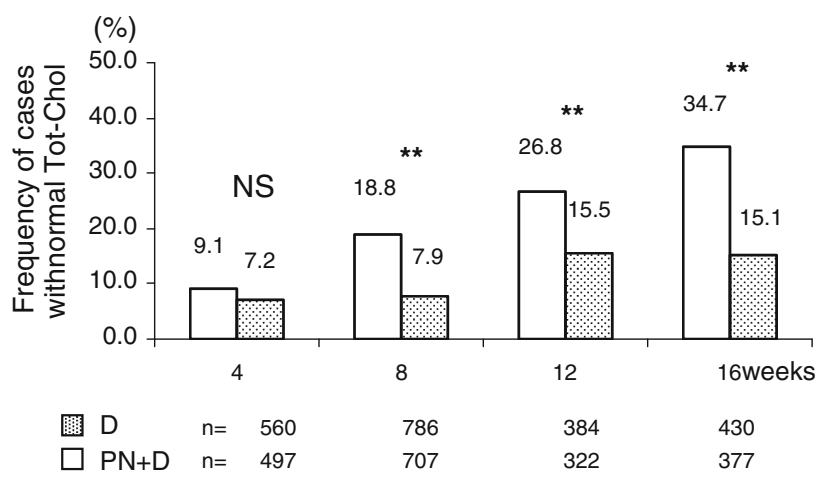

Fig. 6 Rate of normalization of total cholesterolemia $(\leq 190 \mathrm{mg} / \mathrm{dL})$ during diet alone or plus PN $(* * p<0.01$ between treatments) 
Table 3 Main unwanted events judged as probably, possibly or certainly related to the treatment

\begin{tabular}{lll}
\hline Treatment No. of cases treated & D 818 & PN + D 933 \\
\hline Constipation & - & 6 \\
Dyspepsia & - & 5 \\
Myalgia & - & 3 \\
Nausea & - & 3 \\
Diarrhea & - & 2 \\
Meteorism & - & 2 \\
Bitter taste & - & 1 \\
Asthenia & - & 1 \\
Headache & 1 & - \\
Vomiting & - & - \\
Dizziness & 1 & - \\
Itching & 1 & - \\
Steatorrhea & 1 & -
\end{tabular}

recommended by the physician and usually not accurately followed by the patients.

Currently, the assortment of nutraceuticals is very wide and in their selection a careful attention should be paid to products that assure a standardized and constant composition and quality and whose claimed clinical efficacy and safety are documented.

The clinical outcome showed the efficacy of the nutraceuticals contained in PN $[4,6,13,14]$ even exhibiting a lipid profile improvement independently of age classes, gender and administration time during the day [16] and the remarkable increase in HDL-Chol observed in patients with metabolic syndrome (MetS). Moreover, PN reduced the incidence of MetS and improved the Framingham Risk Score achieving a significant change of global CV risk class versus $\mathrm{D}$ [17]. The positive correlation between the level of LDLChol at the beginning of PN treatment and the decrease of LDL-Chol achieved after 12 weeks does not limit the use of PN to subjects with mild hypercholesterolemia.

An important feature of PN is its good safety as shown by the very low incidence of adverse reactions such as constipation $(0.6 \%)$, dyspepsia $(0.5 \%)$, nausea $(0.3 \%)$, and diarrhoea $(0.2 \%)$. The onset of myalgia, the adverse event more worried the patients because it impairs their quality of life, occurs in a low number of cases $(0.3 \%)$, as compared to statins, and required a precautionary withdrawal of treatment in one patient $(0.1 \%)$. In a long term study where the patients were the controls of themselves, patients were previously intolerant to more than one statin significantly improved their blood lipid picture without complaining side effects [6]. This favorable safety profile allows to administer PN even in patients that, according to international guidelines for higher added cardiovascular disease risk, should be treated with statins. The occurrence of myalgia is linked to monacolin $\mathrm{K}$, whose molecular structure correspond to a that of a mild statin. The rare incidence of this side-effect in the PN $+\mathrm{D}$ group is due to the low daily dose of monacolin $\mathrm{K}$ in PN, classified as food supplement, as compared to the correspondent statin prescription drug ( $3 \mathrm{mg}$ versus the smallest $10 \mathrm{mg}$ therapeutic dose of lovastatin). Notwithstanding the small dose of monacolin, PN was effective as the action of monacolin $\mathrm{K}$ is integrated by the whole monacolins family contained in red yeast rice extract and by the synergistic action of berberine and policosanol. In facts, berberine increases LDLR expression by a mechanism distinct from statins and monacolin $\mathrm{K}$, inhibitors of 3-hydroxy-3-methylglutarylCoenzime A reductase. Experimental data provide evidence that berberine and lovastatin had additive stimulating effects on LDLR mRNA expression and that berberine activity was not reduced at all by lovastatin [15]. These results show the synergy of action of the combination among berberine, red yeast rice and policosanol, previously found in an animal study.

As final conclusion, the variety of the available data supports the rationale for recommending the PN combination of nutraceuticals with lifestyle changes and a balanced diet as an effective approach to dyslipidemic patients $[4,5,17]$.

Acknowledgments We thank Ibis Informatica for the website and database development and Angela Ponzoni for the organizing assistance to the project.

\section{Conflict of interest None.}

Open Access This article is distributed under the terms of the Creative Commons Attribution Noncommercial License which permits any noncommercial use, distribution, and reproduction in any medium, provided the original author(s) and source are credited.

\section{Armoweb study group}

Abbondandolo A, Avellino; Adreani L, Cugliate (VA); Agosta S, Ragusa; Amalfitano F, Ischia Porto (NA); Amodio M, Salerno; Angrisani S, Salerno; Attianese P, Nocera Inf (SA); Baracchi A, Genova; Baraldi G, Mirandola (MO); Bastianelli M, Palestrina (RM); Belfiore A, Napoli; Bellucci L, Napoli; Bernardelli S, S.Benedetto Po (MN); Bersani S, Monteveglio (BO); Bertani F, Legnaro (PD); Bertazzoni M, Castelleone (CR); Bevilacqua D, Avellino; Bifarella M, Catania; Bocchi A, Carpi (MO); Bocchia A, Caprana (SP); Bonacchi G, Quarrata (PT); Bondi F, Castiglione Delle Stiviere (MN); Bove F, M.Procida (NA); Brancato T, Napoli; Bruzzese G, Napoli; Buricchi S, Signa (FI); Caccamo O, Gela (CL); Caccialupi A, Roma; Cacciotti R, Roma; Campanelli A, Bologna; 
Campisi A, Messina; Canale G, Nocera Inf (SA); Capasso A, C/Mare Di Stabia (NA); Cardamone N, Catanzaro; Carletti S, Roma; Casati S, Cantu' (CO); Casciello A, Salerno; Cascone E, Pagani (SA); Catalano A, Salerno; Caverzasio Ferloni S, Cadegliano (VA); Cavi G, Gazzada Schianno (VA); Cazzuoli L, Mirandola (MO); Ceccherini R, Pisa; Cella F, Genova; Celsi A, Cinisello B. (M); Cerracchio A, Napoli; Chiaro G, Mirano (VE); Chierici S, Castel San Pietro (BO); Chiurlia E, Modena; Cintura R, Quartu S. Elena (CA); Citarda M, Palermo; Cocchi C, Parma; Coco S, Lentini (SR); Colle R, Udine; Colurcio R, Casoria (NA); Corretti G, Livorno; Coscione M, Napoli; Cricco L, Montefiascone (VT); Damasco A, Monterotondo (RM); De Crignis S, Santa Maria Mole (RM); De Donato M, Salerno; De Lucia L, Roma; De Marco M, Cosenza; De Maria G, Agliano T. (AT); De Panfilis G, Ortona (CH); De Simone A, Casavatore (NA); De Simone S, Roma; Del Castillo R, Palermo; Della Sala W, Pozzo D’Adda (MI); Desenzani P, Montichiari (BS); Di Martino M, Vico Equense (NA); Di Palo M, Napoli; Dighero A, Loano (SV); Donzelli L, Scanzorosciate (BG); Esposito E, Napoli; Fallone B, Roma; Farci G, Cagliari; Fedeli G, Guidonia (RM); Ferrara G, Omegna (VB); Ferrari Tovoli, Bologna; Ferraro S, Napoli; Filipponi S, Rieti; Finazzi A, Gromello (BG); Fiorillo V, Casalnuovo (NA); Fodale P, Messina; Fornara S, Borgomanero (NO); Forni A, Ponticelli (NA); Foti V, Taranto; Fresa U, C/Mare Di Stabia (NA); Gambarelli M, Roncobello (BG); Garozzo S, Acicatena (CT); Gatti G, Francavilla (BR); Gatti C, Ancona; Giarrizzo G; Giobbe G, Roma; Giordano G, S.Maria Capua Vetere (CE); Giordano L, Gragnano (NA); Giubilei R, Roma; Giuliani G, Castronno (VA); Granata G, Ortona (CH); Grassetti C, Todi (PG); Grassi P, Sarzana (SP); Grimaldi I, Roma; Gruppillo P, Ferrara; Gualandra R, Bologna; Guerrera L, Casalduini (BN); Guida B, Napoli; Guidi M, Bazzano (BO); Guidorizzi A, Savigno (BO); Handshin F, Bergamo; Iacotucci A, Itri (LT); Iacovella C, Roccasecca (FR); Iannotta V, Salerno; Iannuzzo D, Napoli; Igne F, Brugnera (PN); Jemoli R, Como; Lanzilli A, Napoli; Lavecchia G, Napoli; Leotta S, Roma; Lettina G, S. Teresa Riva (ME); Librizzi S, Capo D’Orlando (ME); Lilla Della Monica G, Sora (FR); Limonta A, Paderno Dugnano (MI); Longo P, Voghera (PV); Luce L, Tradate (VA); Luongo C, Formia (RM); Lustri G, Avezzano (AQ); Mancino A, Caserta; Marchetti F, Poggibonsi (SI); Marchi P, Tresigallo (FE); Marchi M, Sassari; Mari E, La Spezia (SP); Martines G, Lentini (SR); Martorelli M, Bologna; Mastrosimone G, Caltanissetta; Matarrese A, S. Benedetto Del Tronto (AP); Mauriello C, Volla (NA); Maurizio W, Ciampino (RM); Mavilla F, Modica (RG); Micantonio L, Roma; Mietto B, S. Francesco Al C. (TO); Miranda C, Nocera Inf (SA); Miranda G, Salerno; Miranda G, Salerno; Moglia G, Voghera (PV); Molaschi M, Segrate (MI); Montanari G,
Casalecchio Di Reno (BO); Montefusco S, Napoli; Montresor G, Brescia; Muscolo A, Catanzaro; Oddino G, Ovada (AL); Onorato R, Malavicina (MN); Orlandi R, Roma; Paladini R, Napoli; Panzieri F, Pescara; Paolini B, Colle Vald'Elsa (SI); Pasquale M, Cittanova (RC); Patella M, Padova; Pensalfine E, Roma; Perri F, Cosenza; Perseghini A, Tortona (AL); Petitto M, Napoli; Petrucci R, Fossombrone (PU); Pezone G, Colle Vald'Elsa (SI); Pierallini D, Roma; Pifferi B, Fabrica Di Roma (VT); Pilo R, Cremona (CR); Pirino R, Albenga (SV); Pirrotta E, Roma; Pisano R, Roma; Plaitano G, Capezzano (SA); Polimeno S, Napoli; Polistina C, Napoli; Poloni F, Palazzo Pigliano (CR); Polti G, Valbrona (CO); Polverino W, Napoli; Porta V, Concorezzo (MI); Potenza F, Pescara; Prampolini M, Fiorano (MO); Prestieri G, Napoli; Principe A, Rende (CS); Raviele P, Avellino; Righetto A, Salzano (VE); Riviello C, Casavatore (NA); Rizzo U, Capurso (BA); Romagnoli G, Bazzano (BO); Romano G, Mili Marina (ME); Romis L, Napoli; Rubini S, Bologna; Russo R, Lecce; Sanna N, Sassari; Santangelo L, Napoli; Santopietro S, Benevento; Saponaro P, Francavilla (BR); Scano G, Selargius (CA); Scrine O, Villa Raspa (PE); Sederino S, Caserta; Seminara G, Padova; Sergi G, Messina; Sfarra A, Ciampino (RM); Signori P, Terni; Silvestri P, Benevento; Simsmieh F, Felegara (PR); Sotgiu P, Bacoli (NA); Spreafico P, Eupilio (CO); Statuti D, Ciampino (RM); Tancini R, Rivarossa (TO); Tanganelli S, Pescia (PT); Tesini N, Savigno (BO); Timi M, Bastia Umbra (PG); Torello C, Nizza Monferrato (AT); Torricella M, Bergamo; Trio R, Napoli; Trotti F, Alessandria (AL); Ursini T, Ascoli Piceno; Vallani F, Nogara (VR); Vanotti A, Como; Vassalle P, Lido Campione (LU); Vasta F, Lamezia (CZ); Velardi M, Atripalda (AV); Veneziani E, Roma; Ventresca E, Ciampino (RM); Vicario A, Avellino; Villani G, Nocera Inf (SA); Vincenzi M, Faenza (RA); Vinci F, Cagliari; Vinci G, Marsala (TP); Zappia C, Massa; Zerella F, Benevento.

\section{References}

1. Hill AM, Fleming JA, Kris-Etherton PM (2009) The role of diet and nutritional supplements in preventing and treating cardiovascular disease. Curr Opin Cardiol 24:433-441

2. ATP III (2001) Executive summary of the third report of the national cholesterol education program (NCEP) expert panel on detection, evaluation and treatment of high blood cholesterol in adults (adult treatment panel III). JAMA 285:2486-2496

3. Smith SC Jr, Allen J, Blair SN, Bonow RO, Brass LM, Fonarow GC et al (2006) AHA/ACC guidelines for secondary prevention for patients with coronary and other atherosclerotic vascular disease: 2006 update endorsed by the National Heart, Lung, and Blood Institute. J Am Coll Cardiol 47:2130-2139

4. Cicero AF, Rovati LC, Setnikar I (2007) Eulipidemic effects of berberine administered alone or in combination with other natural cholesterol lowering agents. A single-blind clinical investigation. Arzneimittelforschung 57:26-30 
5. Rumawas ME, Meigs JB, Dwyer JT, McKeown NM, Jacques PF (2009) Mediterranean-style dietary pattern, reduced risk of metabolic syndrome traits, and incidence in the Framingham offspring cohort. Am J Clin Nutr 90:1608-1614

6. Cicero AFG, Derosa G, Bove M, Borghi C, Gaddi AV (2009) Long-term effectiveness and safety of a nutraceutical based approach to reduce cholesterolemia in statin intolerant subjects with and without metabolic syndrome. Curr Topics Nutraceutical Res 7 (in press)

7. Setnikar I, Senin P, Rovati LC (2005) Antiatherosclerotic efficacy of policosanol, red yeast rice extract and astaxanthin in the rabbit Arzneimittel-Forschung (Drug Research) 55:312-317

8. Homocysteine Lowering Trialists' Collaboration (2005) Dosedependent effects of folic acid on blood concentrations of homocysteine: a meta-analysis of the randomized trials. Am J Clin Nutr 82:806-812

9. Cohen J (1992) A power primer. Psychol Bull 112(1):155-159

10. Heber D, Yip I, Ashley JM, Elashoff DA, Elashoff RM, Liang V, Go W (1999) Cholesterol-lowering effects of a proprietary chinese red-yeast rice dietary supplement. Am J Clin Nutr 69:231-236

11. Wang J, Su M, Lu Z et al (1995) Clinical trial of extract of Monascus purpureus (red yeast) in the treatment of hyperlipidemia. Chin J Exp Ther Prep Chin Med 12:1-5
12. Brusq J-M, Ancellin N, Grondin P, Guillard R, Martin S, Sainillan Y et al (2006) Inhibition of lipid synthesis through activation of AMP-kinase: an additional mechanism for the hypolipemic effect of berberine. J Lipid Res Feb 28 (epub)

13. Cicero AFG, Ertek S (2009) Metabolic and cardiovascular effects of berberine: from preclinical evidences to clinical trial results. Clin Lipidol 4:553-563

14. Caputi AP, Benvenuti C (2008) Armoweb Study Group improving the diet efficacy in hypercholesterolemic subjects with red yeast rice plus policosanol. L'Internista/Medicina Clinica.it 16:53-60

15. Kong W, Wei J, Abidi P, Lin M, Inaba S, Li C, Wang Y, Wang Z, Si S, Pan H, Wang S, Wu J, Wang Y, Li Z, Liu J, Jiang JD (2004) Berberine is a novel cholesterol-lowering drug working through a unique mechanism distinct from statins. Nat Med 10:1344-1351

16. Cicero AFG, Benvenuti C (2010) ARMoweb study Group Efficacy of a red yeast rice based nutraceutical in large subgroups of hypercholesterolemic subjects in every day clinical practice. Mediter J Nutr Metabol (in press)

17. Izzo R, de Simone G, Giudice R, Chinali M, Trimarco V, De Luca N, Trimarco B (2010) Effects of nutraceuticals on prevalence of metabolic syndrome and on calculated Framingham risk score in subjects with dyslipidemia. J Hypertension (in press) 